\title{
HIGH TRANSPLANT DENSITY CAUSE LOSS YIELD AND QUALITY DECREMENT BY AFFECTING PHOTOSYNTHESIS, DRY MATTER ACCUMULATION AND TRANSPORTATION IN SUPER RICE
}

\author{
DUAN, M. Y. ${ }^{1,2 \#}-$ LUO, H. W. ${ }^{1,2 \#}-$ PAN, S. G. ${ }^{1,2}-$ Mo, Z. M. ${ }^{1,2}-$ YANG, X. J. ${ }^{1,2}-$ TIAN, J. Y. ${ }^{1,2}-$ \\ NIE, J. ${ }^{1,2}-$ WANG, H. X. ${ }^{1,2}-$ LI, L. ${ }^{1,2}-$ TANG, X. R. ${ }^{1,2^{*}}$ \\ ${ }^{I}$ Department of Crop Science and Technology, College of Agriculture, South China Agricultural \\ University, 2018, 510642, PR China \\ ${ }^{2}$ Scientific Observing and Experimental Station of Crop Cultivation in South China, Ministry of \\ Agriculture, 2018, 510642, PR China \\ ${ }^{\#}$ These author have contributed equally to this work. \\ *Corresponding author \\ e-mail:tangxr@scau.edu.cn \\ (Received 23 ${ }^{\text {rd }}$ Feb 2019; accepted 21 ${ }^{\text {st }}$ Mar 2019)
}

\begin{abstract}
Transplant density is an important factor which has impacts on rice growth and development in transplanted rice production system. Present study used three transplant densities in paddy field experiment and set as D1 (transplant spacing of $20 \mathrm{~cm} \times 24 \mathrm{~cm}$, about 2.085 hundred thousand hills for each hectare), D2 (transplant spacing of $20 \mathrm{~cm} \times 20 \mathrm{~cm}$, about 2.603 hundred thousand hills for each hectare) and D3 (transplant spacing of $20 \mathrm{~cm} \times 16 \mathrm{~cm}$, about 3.120 hundred thousand hills for each hectare). The results showed that high density (D3) not only reduced the net photosynthetic rate and LAI values at heading stage, but also decreased dry matter accumulation and transportation compared to D1 density. The highest yield was recorded in D1 density and the lowest yield was recorded in D3 density. Study also revealed that high density caused yield loss by decreasing the grain number and seed-setting rate. Furthermore, high density also increased chalk rice rate and chalkiness while reducing the amylose content. The activity of sucrose synthase (SS) in D3 was significantly lower than D1 and it might relate to the reduction of grain quality.
\end{abstract}

Keyword: rice, density, yield, quality, net photosynthetic rate, dry matter accumulation and transportation

\section{Introduction}

Rice (Oryza sativa L.) is a main crop which has been cultivated in China, its production plays an important role in Chinese food security. In recent years, because the area of arable lands is in rapid decline, how to maintain the rice productivity and promote the yield potential had been the main research direction for many experts in last decade (Tao et al., 2019; Tang et al., 2019). There are a lot of factors that could affect grain yield and quality of rice. For example, the transplant density is a key part which affects grain yield and quality significantly in rice production.

Rational close planting is one of the important strategies for high yield and good quality cultivation of rice. A suitable transplanted density not only could give full play to the strong tillering and self-regulation ability of rice population, reduce the competition of inter-row and inter-plant growth in rice population, and avoid the overgrowth of early growth, but also ensure that the rice field can make full use of light energy, carry out photosynthesis, accumulate more organic matter, thereby increasing 
rice yield (Zhou et al., 2018; Huang et al., 2018; Tareq et al., 2018). In 2001, Yuan demonstrated that low plant density enlarged the growth space of above-ground and below-ground parts of rice, enlarges individual strength and panicle size, thus gaining high yield. The study of Hayashi et al. (2006) revealed that over-dense planting strengthens the competition of photosynthetic nutrients among rice individuals and promotes early flowering of rice. Furthermore, Mobasser et al. (2009) indicated that low density treatment could increase the conversion rate and output rate of stem and sheath substances and finally increased rice yield.

High yield and good quality of rice are the major goals in rice production and in transplanted rice production system, suitable transplant density is an important part to gain those two goals. Thus, we explored the process of photosynthesis, dry matter accumulation and transportation in order to study the response of super rice yield and quality under high transplant density in present study.

\section{Materials and Methods}

\section{Plant materials and growing condition}

A super hybrid rice variety, Huahang31, a well-known and widely grown in South China, were in planted during the late season (July-November) in 2010 and the early season (March-July) in 2011 at the College of Agriculture's Experimental Farm, South China Agricultural University (SCAU), Guangzhou, Guangdong Province, China $\left(23^{\circ} 16^{\prime} \mathrm{N}, 113^{\circ} 23^{\prime}\right.$ E, elevation $\left.11 \mathrm{~m}\right)$. The air temperature was shown in Figure 1.

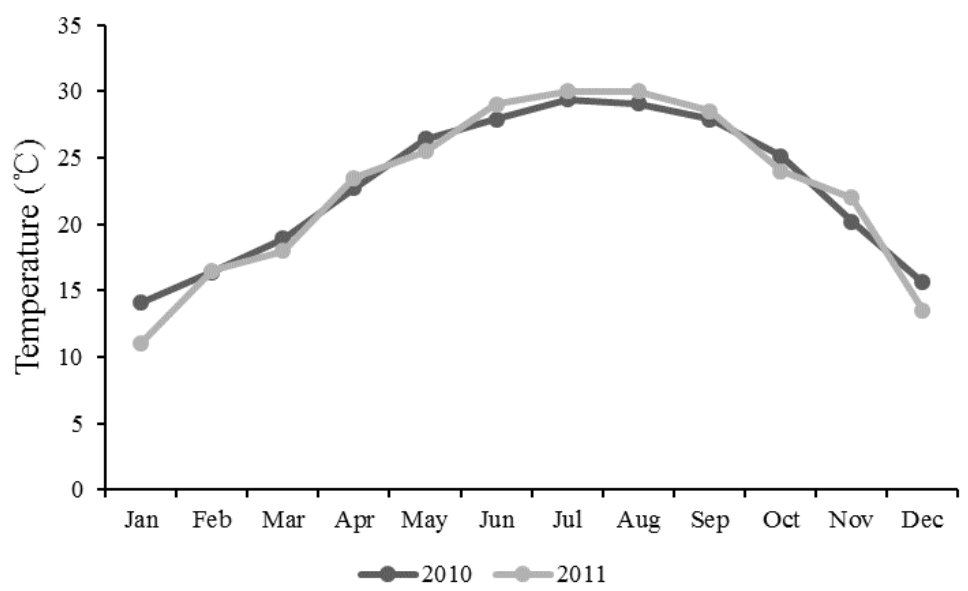

Figure 1. Mean monthly air temperature in Guangzhou during 2010 and 2011 (Annual average temperature in 2010 was $22.81^{\circ} \mathrm{C}$ and in 2011 was $22.63^{\circ} \mathrm{C}$

Before sowing, the seeds were soaked in water for $24 \mathrm{~h}$, germinated in manual climatic box for the next $24 \mathrm{~h}$, shade dried and the germinated seeds were sown in PVC trays for nursery raising. 15-day-old seedlings and 25-day-old seedlings were transplanted to the field in 2010 and 2011, respectively. The experimental soil has been planted rice for many years and it was sandy loam with of $16.80 \mathrm{~g} \mathrm{~kg}^{-1}$ organic matter content, $1.032 \mathrm{~g} \mathrm{~kg}^{-1}$ total $\mathrm{N}, 0.998 \mathrm{~g} \mathrm{~kg}^{-1}$ total $\mathrm{P}, 13.598 \mathrm{~g} \mathrm{~kg}^{-1}$ total $\mathrm{K}, 84.60 \mathrm{mg} \mathrm{kg}^{-1}$ available $\mathrm{N}, 43.58 \mathrm{mg} \mathrm{kg}^{-1}$ available $\mathrm{P}$, and $106.10 \mathrm{mg} \mathrm{kg}^{-1}$ available $\mathrm{K}$. 


\section{Treatments descriptions}

Three transplanted densities were applied at the experiment and set as blow.

- D1: Seedlings were transplanted at the rate of 2 seedlings per hill at a spacing of $20 \mathrm{~cm} \times 24 \mathrm{~cm}$, about 0.2085 million hills per hectare.

- D2: Seedlings were transplanted at the rate of 2 seedlings per hill at a spacing of $20 \mathrm{~cm} \times 20 \mathrm{~cm}$, about 0.2505 million hills per hectare.

- D3: Seedlings were transplanted at the rate of 2 seedlings per hill at a spacing of $20 \mathrm{~cm} \times 16 \mathrm{~cm}$, about 0.3120 million hills per hectare.

Commercial compound fertilizer (Total nitrogen contents $\mathrm{TN}=15 \%$, $\mathrm{K} 2 \mathrm{O}$ contents $=12 \%, \mathrm{P} 2 \mathrm{O} 5$ contents $=7.2 \%$ ) was applied at the same amount of $1500 \mathrm{~kg} \mathrm{ha}^{-1} .80 \%$ of fertilizer was applied as basal and $20 \%$ was top-dressed at tillering stage.

\section{Plant sampling and determination of biomass accumulation}

At tillering stage, heading stage and maturity, the rice plants were harvested from fifteens hills in each plot. The leave, stems and grain were separated from the plants and dried Under the condition of $80^{\circ} \mathrm{C}$ respectively in order to get the estimation of dry matter. The output rate of stem matter (OPRS) was calculated as:

$$
\mathrm{OPRS}=\frac{(\text { stem weight at heading stage }- \text { stem weight at maturity) }}{\text { stem weight at heading stage }}
$$

The conversion rate of stem matter (CRS) was calculated as:

$$
\mathrm{CRS}=\frac{\text { (stem weight at heading stage }- \text { stem weight at maturity) }}{\text { grain weight at maturity }}
$$

The fresh grains were separated and collected from the rice plants 7 th day after heading stage, washed with double distilled water and stored Under the condition of $-80^{\circ} \mathrm{C}$ for the estimation of sucrose synthase (SS), soluble starch synthase (SSS) and Bound starch synthase (GBSS).

\section{Determination of photosynthesis, SPAD and Leaf area index (LAI)}

Portable photosynthesis system (LI-6400, LI-COR, USA) was used to determine net photosynthetic rate at 09:00-10:30 a.m. according to the standard method (Pan et al., 2016). SPAD meter 'SPAD-502' (Konica Minolta, Japan) was used for precise, rapid and non-destructive estimation of leaf chlorophyll contents. At tillering stage, heading stage and maturity, the rice plants were harvested from ten hills in each plot. The leaves were separated from main plants and the green leaves area was measured by a leaf area meter (CID-202, Lincoln, NE, USA) to determine the leaf area index (LAI).

\section{Determination of activities of sucrose synthase (SS)}

The activity of SS was measured according to the method described by $\mathrm{Li}$ et al. (2008). The activity of SS was determinate in both saturating and selective (limiting) conditions. The limiting assay consisted of the same reaction mixture except that $10 \mathrm{mmol} \mathrm{L}^{-1} \mathrm{Pi}$ was added and the concentrations of uridine diphosphate glucose 
(UDPG), fructose, and glucose-6-P were reduced to 2,2 and $10 \mathrm{mmol} \mathrm{L}^{-1}$. The reaction was terminated by using $1 \mathrm{~mol} \mathrm{~L}^{-1} \mathrm{NaOH}$ and the mixture was boiled to degrade any unreacted fructose-6-P. After cooling, $0.20 \mathrm{~mL}$ of $0.1 \%(\mathrm{w} / \mathrm{v})$ resorcinol in $95 \%$ ethanol and $0.80 \mathrm{~mL}$ of $9 \mathrm{mmol} \mathrm{L}-1 \mathrm{HCl}$ were added and the tubes were incubated at $80^{\circ} \mathrm{C}$ for $10 \mathrm{~min}$. Three separate extractions of grain powder were assayed for the activities of enzymes. The activities of SS were shown as specific activities $\left(\mathrm{g}^{-1} \mathrm{FW} \mathrm{h}^{-1}\right)$.

\section{Determination of activities of soluble starch synthase (SSS) and granule-bound starch synthase (GBSS)}

The activity of SSS and GBSS was determined by Nakamura and Yuki (1992). Twenty shelled grains of the same part were accurately weighed and placed in a precooled mortar. The supernatant was extracted with $4 \mathrm{ml}$ extract (containing $100 \mathrm{mmol}$ $\mathrm{L}^{-1} \mathrm{Ph} 7.5$ Hepes-NaOH buffer, 8 mmol L-1 $\mathrm{MgCl}_{2} 6 \mathrm{H}_{2} \mathrm{O}, 2$ mmol L ${ }^{-1}$ EDTA-Na2, $12.5 \%$ (v/v) glycerol, $1 \%(\mathrm{w} / \mathrm{v})$ PVP-40, $50 \mathrm{mmolL}^{-1}$ mercaptoethanol) by grinding in an ice bath. The supernatant was extracted by centrifugation at $12000 \mathrm{G}$ for $30 \mathrm{~min}$.

SSS activity determination: $1.5 \mathrm{ml}$ centrifuge tube was taken and $20 \mathrm{ml}$ crude enzyme solution was added in turn into $20 \mathrm{ml}$ crude enzyme liquid, $36 \mu \mathrm{l}$ reaction liquid A (containing $50 \mathrm{mmol} \mathrm{L}^{-1} \mathrm{pH} 7.4$ Hepes- $\mathrm{NaOH}$, Hepes- $\mathrm{NaOH}, 1.6 \mathrm{mmol} \mathrm{L}-1$ ADPG, $0.7 \mathrm{mg}$ amylose and $15 \mathrm{mmol} \mathrm{L}^{-1} \mathrm{DTT}$ ) was reacted at $30^{\circ} \mathrm{C}$ for 20 minutes and then boiling water for $30 \mathrm{~s}$ to stopped reaction and ice bath cooled; $20 \mu 1$ reaction liquid $\mathrm{B}$ (containing 50 mmol L ${ }^{-1}$ pH7.4 Hepes- $\mathrm{NaOH}, 4$ mmol L-1 $\mathrm{mmol} \mathrm{L}^{-1} \mathrm{MgCl}_{2} 6 \mathrm{H}_{2} \mathrm{O}$ and 1.2 unit pyruvate kinase reacted at $30^{\circ} \mathrm{C}$ for 20 minutes, then boiling water terminated the reaction for 30 seconds and centrifuged for $10000 \mathrm{~g}$ for 10 minutes. The supernatant was extracted at $60 \mu \mathrm{l}$ and added to $43 \mu \mathrm{l}$ reaction liquid $\mathrm{C}$ (containing $50 \mathrm{mmol} \mathrm{L}^{-1}$ pH7.4 Hepes- $\mathrm{NaOH}, 10 \mathrm{mmol} \mathrm{L}{ }^{-1}$ glucose, $20 \mathrm{mmol} \mathrm{L}^{-1} \mathrm{MgCl}_{2} 6 \mathrm{H}_{2} \mathrm{O}, 2 \mathrm{mmol} \mathrm{L}^{-1}$ NADP, 1.4 unit hexokinase and 0.35 unit glucose-6-phosphate dehydrogenase) for 10 minutes. The absorbance at $340 \mathrm{~nm}$ was determined after reaction at $30^{\circ} \mathrm{C}$.

GBSS activity determination: The subsoil of SSS crude extract was washed twice with $1 \mathrm{ml}$ extract and centrifuged for 20 minutes at $4^{\circ} \mathrm{C}$ for $3000 \mathrm{~g}$. Then the crude enzyme solution of GBSS was obtained by centrifuging the $3 \mathrm{ml}$ extract at $4^{\circ} \mathrm{C}$ for 24 hours and $12000 \mathrm{~g}$ at $2^{\circ} \mathrm{C}$ for 30 minutes. A $1.5 \mathrm{ml}$ centrifugal tube was used, $20 \mu 1$ GBSS crude enzyme was added in turn, $36 \mu 1$ reaction liquid A (containing $50 \mathrm{mmol} \mathrm{L}^{-1}$ pH7.4 Hepes-NaOH, $1.6 \mathrm{mmol} \mathrm{L}^{-1}$ ADPG, $15 \mathrm{mmol} \mathrm{L}^{-1}$ DTT), the other two reaction liquids and reaction process were the same as SSS determination.

\section{Estimation of rice yield and related attributes}

At maturity stage, the rice grains were harvested from ten unit sampling area $\left(10.00 \mathrm{~m}^{2}\right)$ in each plot and then threshed by machine. The harvested grains were sundried and weighed in order to determinate the grain yield. Twenty hills of rice from different locations in each plot were sampled for estimating the average effective panicles number per hill. Then, three hills representative plants were taken for estimation of the yield related traits.

\section{Estimation of grain quality}

Dry grains were stored at room temperature for two months to determine grain quality attributes. About $1.00 \mathrm{~kg}$ rice grains from each treatment was taken from storage and brown rice rate was determined by rice huller (Jiangsu, China) while brown rice and 
head rice rates were calculated by using a Jingmi testing rice grader (Zhejiang, China). Grains with chalkiness and chalkiness degree were determined using an SDE-A light box (Guangzhou, China) while an Infratec-1241 grain analyzer (FOSS-TECATOR) was used to measure the grain amylose and protein contents.

\section{Statistical analysis}

Data were analyzed by using statistical software 'Statistix 8.1'(Analytical Software, Tallahassee, FL, USA) while differences amongst means were separated by using least significant difference (LSD) test at 5\% probability level. Graphical representation was conducted via Sigma Plot 14.0 (Systat Software Inc., California, USA).

\section{Result}

\section{Yield and yield components}

As shown in Table 1, transplant densities affected rice yield and its components differently. High density could significantly increase panicle number and the highest panicle number was recorded in D3 in both years. However, we observed that the lowest yield was recorded in D3 for 2010 and 2011 and the yield in D3 was significantly lower than D1. The decrement of yield was due to the reduction in both grains number and seed setting rate. Compared to D1, D3 treatment remarkably reduced seed setting rate and grain number. Moreover, there was no significant difference among D1, D2 and D3 in 1000-grain weight.

Table 1. Effect of transplant densities on rice yield and its components

\begin{tabular}{|c|c|c|c|c|c|c|}
\hline Year & $\begin{array}{c}\text { Transplant } \\
\text { density }\end{array}$ & $\begin{array}{c}\text { Panicle number } \\
10^{4} \mathrm{hm}^{-2}\end{array}$ & $\begin{array}{c}\text { Grain number } \\
\text { per panicle }\end{array}$ & $\begin{array}{c}\text { Seed setting } \\
\text { rate }(\%)\end{array}$ & $\begin{array}{l}\text { 1000-grain } \\
\text { weight (g) }\end{array}$ & $\begin{array}{l}\text { Yield } \\
\left(\mathrm{t} \mathrm{ha}^{-2}\right)\end{array}$ \\
\hline \multicolumn{7}{|l|}{2010} \\
\hline & D1 & $270.83 b$ & $132.33 \mathrm{a}$ & $88.56 \mathrm{a}$ & $22.99 a$ & $7.30 \mathrm{a}$ \\
\hline & $\mathrm{D} 2$ & $271.67 \mathrm{~b}$ & $133.67 \mathrm{a}$ & $88.18 \mathrm{a}$ & $23.37 \mathrm{a}$ & $6.92 b$ \\
\hline & D3 & $295.14 \mathrm{a}$ & $120.00 b$ & $87.90 \mathrm{~b}$ & $23.26 \mathrm{a}$ & $7.02 b$ \\
\hline \multicolumn{7}{|l|}{2011} \\
\hline & D1 & $230.67 \mathrm{c}$ & $153.33 \mathrm{a}$ & $91.25 \mathrm{a}$ & $23.43 \mathrm{a}$ & $7.70 \mathrm{a}$ \\
\hline & D2 & $273.33 b$ & $138.00 \mathrm{~b}$ & $88.18 b$ & $23.49 \mathrm{a}$ & $7.55 \mathrm{a}$ \\
\hline & D3 & $298.00 \mathrm{a}$ & $117.67 \mathrm{c}$ & $88.57 \mathrm{~b}$ & $23.29 \mathrm{a}$ & $7.12 b$ \\
\hline \multicolumn{7}{|c|}{ Analysis of variance } \\
\hline & sity (D) & $* *$ & $* *$ & $\mathrm{~ns}$ & $\mathrm{~ns}$ & $\mathrm{~ns}$ \\
\hline & $\operatorname{ar}(\mathrm{Y})$ & ns & $\mathrm{ns}$ & $*$ & $* *$ & $*$ \\
\hline & $\times Y$ & ns & $\mathrm{ns}$ & $\mathrm{ns}$ & $*$ & $\mathrm{~ns}$ \\
\hline
\end{tabular}

Data are expressed as the mean of three replications. Values followed by different letters within the same column are significant different at $\mathrm{P}<0.05$ probability level. NS means non-significant differences; $*$ and $* *$ indicated significant differences at 0.05 and 0.01 probability levels, respectively. The same as belowed

\section{Grain quality and its attributes}

As shown in Table 2, there was no significant difference among D1, D2 and D3 in both brown rice rate and head rice rate. However, compared to D1 treatment, D2 and D3 treatments significant increased chalky rice rate in 2010 and 2011. D3 treatment also 
increased chalkiness remarkably for both years. Furthermore, the lower amylose content was recorded in D3 than D1 for 2010 and 2011.

Table 2. Effect of transplant densities on grain quality and its attributes

\begin{tabular}{|c|c|c|c|c|c|c|}
\hline Year & $\begin{array}{c}\text { Transplant } \\
\text { density }\end{array}$ & $\begin{array}{c}\text { Brown rice } \\
\text { rate }(\%)\end{array}$ & $\begin{array}{l}\text { Head rice } \\
\text { rate }(\%)\end{array}$ & $\begin{array}{c}\text { Chalky rice } \\
\text { rate }(\%)\end{array}$ & $\begin{array}{c}\text { Chalkiness } \\
(\%)\end{array}$ & $\begin{array}{c}\text { Amylose content } \\
(\%)\end{array}$ \\
\hline \multicolumn{7}{|l|}{2010} \\
\hline & D1 & $81.72 \mathrm{a}$ & $44.64 \mathrm{a}$ & $4.00 \mathrm{~b}$ & $2.13 \mathrm{~b}$ & $18.07 \mathrm{a}$ \\
\hline & D2 & $81.55 \mathrm{a}$ & $43.64 a$ & $5.33 \mathrm{a}$ & $3.35 \mathrm{a}$ & $18.10 \mathrm{a}$ \\
\hline & D3 & $81.82 \mathrm{a}$ & $45.80 \mathrm{a}$ & $5.67 \mathrm{a}$ & $3.6 \mathrm{a}$ & $17.77 \mathrm{~b}$ \\
\hline \multicolumn{7}{|l|}{2011} \\
\hline & D1 & $80.67 \mathrm{a}$ & $41.99 \mathrm{a}$ & $8.00 \mathrm{~b}$ & $5.10 \mathrm{~b}$ & $18.00 \mathrm{a}$ \\
\hline & D2 & $80.57 \mathrm{a}$ & $40.65 \mathrm{a}$ & $10.67 \mathrm{a}$ & $5.33 \mathrm{ab}$ & $18.00 \mathrm{a}$ \\
\hline & D3 & $80.80 \mathrm{a}$ & $42.67 \mathrm{a}$ & $11.33 \mathrm{a}$ & $5.70 \mathrm{a}$ & $17.80 \mathrm{~b}$ \\
\hline \multicolumn{7}{|c|}{ Analysis of variance } \\
\hline & ity (D) & ** & ns & * & * & * \\
\hline & a $(\mathrm{Y})$ & ** & ** & ** & * & ns \\
\hline & $\times \mathrm{Y}$ & ns & $\mathrm{ns}$ & * & ** & ns \\
\hline
\end{tabular}

\section{Net photosynthetic rate, LAI and SPAD values}

The difference in transplant density could significantly affect rice photosynthesis (Figure 2). At tillering stage, heading stage and maturity in 2010, the net photosynthetic rate in D3 was significantly lower than D1 whilst in 2011, only at heading stage the net photosynthetic rate in D3 was remarkably lower than D1. Compared to D1, D3 treatment significantly decreased $L A I$ values at heading stage for both years. Furthermore, we observed that the SPAD values in D2 and D3 were remarkably lower than D1 at heading stage and maturity in 2010. However, in 2011, there was no significant difference among D1, D2 and D3 in all growth stages.

\section{Dry matter accumulation and transportation}

As shown in Table 3, different densities affected dry matter weight differently. At tillering stage, D3 density significantly decreased leaf weight and stem weight compared to D1 in 2010. The leaf weight, stem weight and grain weight at both heading stage and maturity in D3 were remarkably lower than D1 for 2010 and 2011. Furthermore, we observed that high density (D3) had negative impact on transportation of stem matter while the lowest OPRS and CRS were also recorded in D3 treatments for both years while there was no significant difference between D1 and D2.

\section{Enzymes involved sucrose biosynthesis}

As shown in Figure 3, different densities affected sucrose biosynthesis in grain in terms of SS, SSS and GBSS activities. For SS activity, D3 and D2 had lower acidity than D1 in 2010 while the trend in 2011 was recorded as: D1 > D2 >D3. Compared to D1, D3 treatment also significant decreased the GBSS and SSS activity in 2010 whilst in 2011, there was no significant difference among D1, D2 and D3 in both GBSS and SSS activity. 

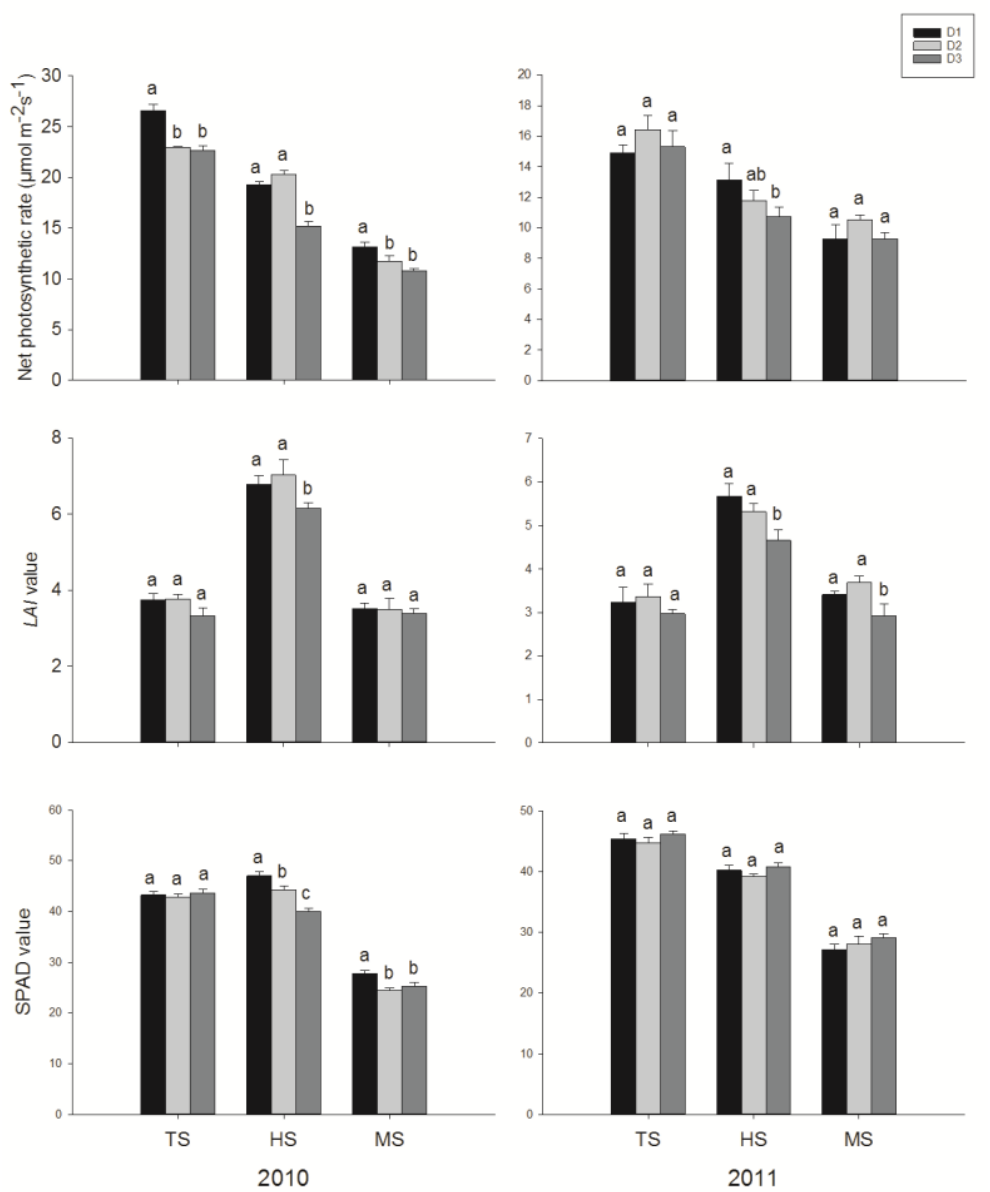

Figure 2. Effect of transplant densities on net photosynthetic rate, LAI and SPAD values.

Capped bars represent S.E. of three replicates. Means sharing a common letter don't differ significantly at $(P \leq 0.05)$ according to least significant difference (LSD) test for both the years.

The same as belowed

Table 3. Effect of transplant densities on dry matter accumulation and transportation

\begin{tabular}{|c|c|c|c|c|c|c|c|c|c|c|c|}
\hline \multirow[b]{2}{*}{ Year } & \multirow[b]{2}{*}{$\begin{array}{c}\text { Transplant } \\
\text { density }\end{array}$} & \multicolumn{2}{|c|}{ TS } & \multicolumn{3}{|c|}{ HS } & \multicolumn{3}{|c|}{ MS } & \multirow[b]{2}{*}{$\begin{array}{c}\text { OPRS } \\
(\%)\end{array}$} & \multirow[b]{2}{*}{$\begin{array}{l}\text { CRS } \\
(\%)\end{array}$} \\
\hline & & $\begin{array}{c}\text { Leaf } \\
\text { weight } \\
\left(\mathrm{g} \mathrm{hill}^{-1}\right)\end{array}$ & $\begin{array}{c}\text { Stem } \\
\text { weight } \\
\left(\mathrm{g} \mathrm{hill}{ }^{-1}\right)\end{array}$ & $\begin{array}{c}\text { Leaf } \\
\text { weight } \\
\left(\mathrm{g} \mathrm{hill}^{-1}\right)\end{array}$ & $\begin{array}{c}\text { Stem } \\
\text { weight } \\
\left(\mathrm{g} \mathrm{hill}{ }^{-1}\right)\end{array}$ & $\begin{array}{c}\text { Grain } \\
\text { weight } \\
\left(\mathrm{g} \mathrm{hill}^{-1}\right) \\
\end{array}$ & $\begin{array}{c}\text { Leaf } \\
\text { weight } \\
\left(\mathrm{g} \mathrm{hill}^{-1}\right)\end{array}$ & $\begin{array}{c}\text { Stem } \\
\text { weight } \\
\left(\mathrm{g} \mathrm{hill}{ }^{-1}\right)\end{array}$ & $\begin{array}{c}\text { Grain } \\
\text { weight } \\
\left(\mathrm{g} \mathrm{hill}^{-1}\right)\end{array}$ & & \\
\hline \multicolumn{12}{|l|}{2010} \\
\hline & D1 & $7.74 \mathrm{a}$ & $6.16 \mathrm{a}$ & $14.07 \mathrm{a}$ & $29.69 \mathrm{a}$ & $9.02 \mathrm{a}$ & $10.69 \mathrm{a}$ & $24.36 \mathrm{a}$ & $36.10 \mathrm{a}$ & $17.95 \mathrm{a}$ & $19.68 \mathrm{a}$ \\
\hline & D2 & $6.38 \mathrm{~b}$ & $5.73 a$ & $13.11 \mathrm{a}$ & $25.25 b$ & $6.62 b$ & $9.07 \mathrm{~b}$ & $19.27 b$ & $33.08 \mathrm{a}$ & $23.68 \mathrm{a}$ & $22.60 \mathrm{a}$ \\
\hline & D3 & $4.97 \mathrm{c}$ & $4.77 \mathrm{~b}$ & $8.50 \mathrm{~b}$ & $15.95 \mathrm{c}$ & $4.71 \mathrm{c}$ & $7.43 \mathrm{c}$ & $15.62 \mathrm{~b}$ & $29.31 b$ & $2.07 \mathrm{~b}$ & $1.34 \mathrm{~b}$ \\
\hline \multicolumn{12}{|l|}{2011} \\
\hline & D1 & $7.22 \mathrm{a}$ & $6.16 \mathrm{a}$ & $11.85 \mathrm{a}$ & $22.02 \mathrm{ab}$ & $18.49 \mathrm{a}$ & $11.85 \mathrm{a}$ & $18.74 \mathrm{a}$ & $47.66 \mathrm{a}$ & $14.90 \mathrm{a}$ & $11.24 \mathrm{a}$ \\
\hline & D2 & $6.90 \mathrm{a}$ & $5.42 \mathrm{a}$ & $12.21 \mathrm{a}$ & $23.15 \mathrm{a}$ & $17.88 \mathrm{ab}$ & $12.21 \mathrm{a}$ & $19.94 \mathrm{a}$ & $53.52 \mathrm{a}$ & $13.87 \mathrm{a}$ & $10.01 \mathrm{a}$ \\
\hline & D3 & $6.59 \mathrm{a}$ & $6.34 \mathrm{a}$ & $9.46 \mathrm{~b}$ & $18.64 \mathrm{~b}$ & $12.45 b$ & $9.46 b$ & $16.51 \mathrm{~b}$ & $38.25 b$ & $11.43 \mathrm{~b}$ & $8.26 \mathrm{~b}$ \\
\hline \multicolumn{12}{|c|}{ Analysis of variance } \\
\hline & nsity (D) & $* *$ & ns & $* *$ & $* *$ & $* *$ & $* *$ & $* *$ & * & $* *$ & $* *$ \\
\hline & $\operatorname{ear}(\mathrm{Y})$ & $\mathrm{ns}$ & ns & ns & ns & $* *$ & ns & ns & $* *$ & $* *$ & $* *$ \\
\hline & $\mathrm{D} \times \mathrm{Y}$ & $\mathrm{ns}$ & $\mathrm{ns}$ & $\mathrm{ns}$ & $*$ & $\mathrm{~ns}$ & $\mathrm{~ns}$ & $\mathrm{~ns}$ & $* *$ & $* *$ & $* *$ \\
\hline
\end{tabular}



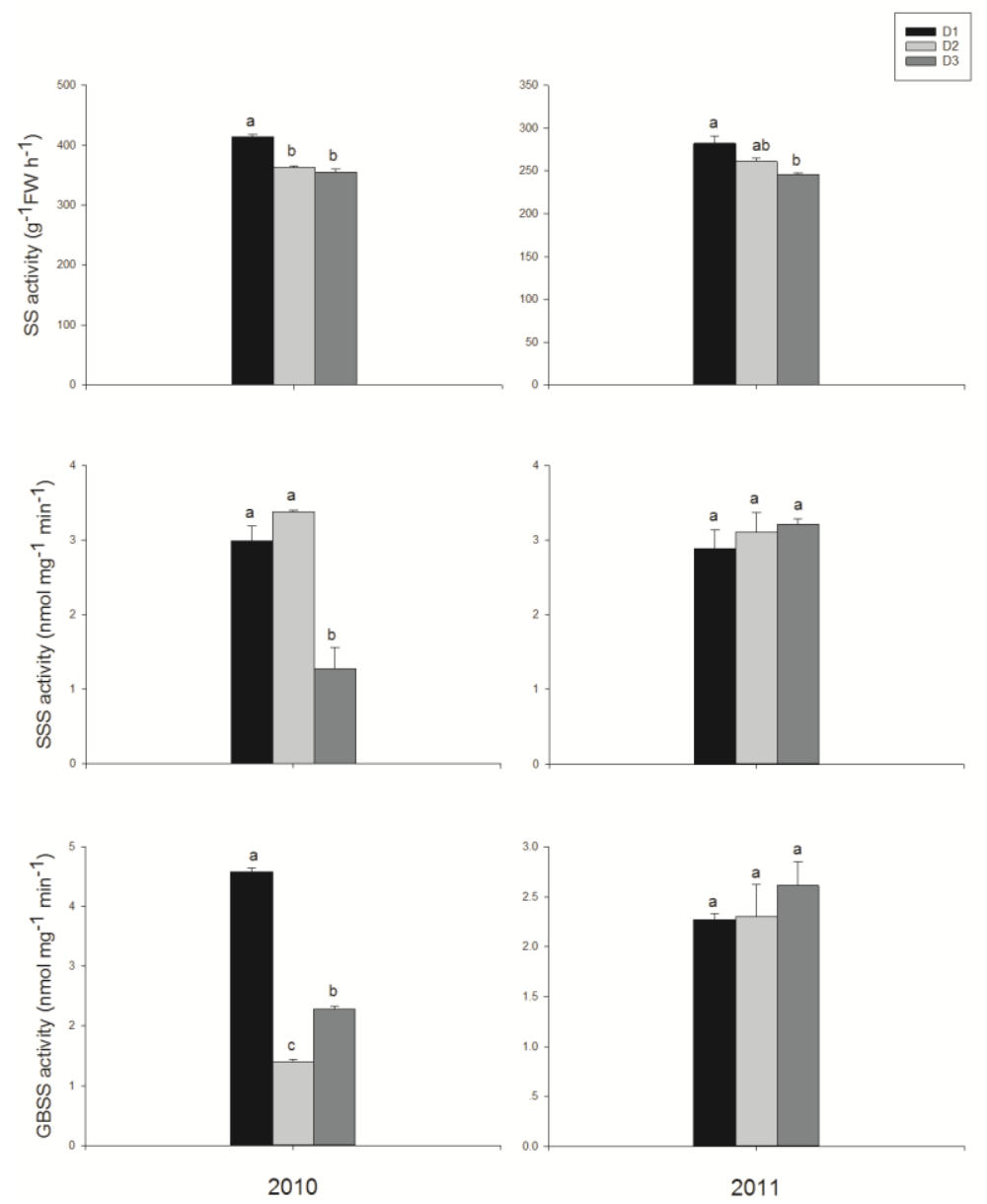

Figure 3. Effect of transplant densities on SS, SSS and GBSS activity

\section{Discussion}

A suitable plant density is one of the decisive factors for harvesting higher grain yield in rice production (Peng et al., 2018; Lee et al., 2018). Normally, the transplant density determines the competition of nutrients such as photosynthesis and fertilizer uptake among rice individuals in the middle and late growth stages among different rice individuals. In our study, we observed that compared to D1, D2 density significantly decreased rice yield in 2010 but there was no difference between D1 and D2. The D3 density remarkably reduced yield by decreasing the grain number and seed setting rate in both years. Present study showed that high density was able to significantly increase panicle number in paddy field, but it would also have negative impacts on other yield components and then still cause the yield loss without yield increment. Similar result was also reported by Zhao (2011) who demonstrated that the yield of surper rice, Y-liangyou 302, was mainly affected by panicles and spikelets per panicle, while the spike length and 1000-grain weight did not showed any significant influence on yield and high nitrogen and low planting density is conducive to increase the yield of rice variety Y-liangyou 302 in north region of Guangxi. The further reason in reduction of yield might be the increment in competition for photosynthesis among rice individuals under high density. Present study showed that D3 treatment not only decreased the net 
photosynthetic rate, but also reduced the $L A I$ values. Leaf area index (LAI) is an important parameter in crop growth status monitoring and yield forecasting (Xue and Wang, 2004). Normally, the values of $L A I$ and net photosynthetic rate represent the intensity of population photosynthesis. In our study, the result indicated that the lower population photosynthesis under high density induced the decrement in dry matter accumulation and inadequate supply of dry matter eventually led to a decline in production. Our finding was also consistent with the research of Sultana et al. (2001) who indicated that dry matter accumulation was an important factor in determining rice yield.

Furthermore, worse grain quality was recorded in D3 treatment than D1. Present study revealed that not only D2 and D3 densities would increase both chalky rice rate and chalkiness, but also D3 density would significantly decreased amylose content. The increment in chalkiness and chalky rice rate might be due to the decrement of net photosynthetic rate at heading stage and the matter transportation from stem to grain. The study of Mo et al. (2015) showed that photosynthesis during the filling stage might had a great impact on grain chalkiness of rice. In 2015, the study of Zhou et al. (2015) found that there was a positive correlation among low amylose content, high degree of endosperm chalkiness and percentage of grains with chalkiness in grain and similar conditions were also observed in our study. The lower amylose content in D3 than D1 could be explained by the reduction in SS activity. Moreover, lower OPRS, CRS and net photosynthetic rate in heading stage also could be responsible for amylose content decrement.

\section{Conclusion}

Present study showed that high transplanted reduced the rice photosynthesism decreased the dry matter accumulation and transportation and finally caused the loss of grain yield. For revealing the mechanism of rice yield and quality formation by transplant density treatments, much work should be done at molecular and physiological level at the field trials.

Acknowledgements. This study was supported by Guangdong science and technology planning project (2011AO2020001), National Natural Science Foundation of China (31271646), the World Bank Loan Agricultural Pollution Control Project in Guangdong (0724-1510A08N3684) and the Technology System of Modern Agricultural Industry in Guangdong (2017LM1098).

\section{REFERENCES}

[1] Hayashi, S., Kamoshita, A., Yamagishi, J. (2006): Effect of planting density on grain yield and water productivity of rice (Oryza sativa L.) grown in flooded and non-flooded fields in Japan. - Plant Production Science 9: 298-311.

[2] Huang, M., Chen, J., Cao, F., Zou, Y. (2018): Increased hill density can compensate for yield loss from reduced nitrogen input in machine-transplanted double-cropped rice. Field Crops Research 221: 333-338.

[3] Lee, J., Wissuwa, M., Zamora, O. B., Ismail, A. M. (2018): Novel Sources of aus Rice for Zinc Deficiency Tolerance Identified Through Association Analysis Using High-Density SNP Array. - Rice Science 25: 293-296. 
[4] Li, J. Y., Liu, X. H., Cai, Q. S., Gu, H., Zhang, S. S., Wu, Y. Y., Wang, C. J. (2008): Effects of Elevated CO2 on Growth, Carbon Assimilation, Photosynthate Accumulation and Related Enzymes in Rice Leaves during Sink-Source Transition. - Journal of Integrative Plant Biology 50: 723-732.

[5] Mo, Z., Li, W., Pan, S., Fitzgerald, T. L., Xiao, F., Tang, Y., Wang, Y., Duan, M., Tian, H., Tang, X. (2015): Shading during the grain filling period increases 2-acetyl-1-pyrroline content in fragrant rice. - Rice 8: 1-10.

[6] Mobasser, H. R., Yadi, R., Azizi, M., Ghanbari, A. M., Samdaliri, M. (2009): Effect of density on morphological characteristics related-lodging on yield and yield components in varieties rice (Oryza sativa L.) in Iran. - American-Eurasian Journal of Agricultural and Environmental Science.

[7] Nakamura, Y., Yuki, K. (1992): Changes in enzyme activities associated with carbohydrate metabolism during the development of rice endosperm. - Plant Science 82: 15-20.

[8] Pan, S., Liu, H., Mo, Z., Patterson, B., Duan, M., Tian, H., Hu, S., Tang, X. (2016): Effects of Nitrogen and Shading on Root Morphologies, Nutrient Accumulation, and Photosynthetic Parameters in Different Rice Genotypes. - Scientific Reports 6.

[9] Peng, B., Feng, G. N., Zhen, Q., Qiu, M. (2018): EFFECTS OF OZONE AND DENSITY INTERACTION ON THE GROWTH, DEVELOPMENT AND YIELD FORMATION OF RICE. - Applied Ecology and Environmental Research 16: 4199-4215.

[10] Sultana, N., Ikeda, T., Kashem, M. A. (2001): Effect of foliar spray of nutrient solutions on photosynthesis, dry matter accumulation and yield in seawater-stressed rice. Environmental \& Experimental Botany 46: 129-140.

[11] Tang, S., Zhang, H., Liu, W., Dou, Z., Zhou, Q., Chen, W., Wang, S., Ding, Y. (2019): Nitrogen fertilizer at heading stage effectively compensates for the deterioration of rice quality by affecting the starch-related properties under elevated temperatures. - Food Chemistry 277: 455-462.

[12] Tao, F., Palosuo, T., Valkama, E., Makipaa, R. (2019): Cropland soils in China have a large potential for carbon sequestration based It on literature survey. - Soil \& Tillage Research 186: 70-78.

[13] Tareq, T. M., Rahman, M. S., Jewel, N. A., Islam, T., Shimono, H., Seraj, Z. I. (2018): Relative Response of Indigenous Rice Genotypes to Low Versus Normal Planting Density for Determination of Differential Phenotypic Plasticity in Traits Related to Grain Yield. - Plant Tissue Culture \& Biotechnology 28: 109-124.

[14] Xue, L. H., Wang, S. H. (2004): Relationship between spectral vegetation indices and LAI in rice. - Acta Phytoecologica Sinica 28: 47-52.

[15] Yuan, L. (2001): The Strategy for Hybrid Rice Development. - Hybrid Rice 4-6.

[16] Zhao, R. D. (2011): Effects of transplanting density and nitrogen fertilizer rate on yield and its components in super-high-yielding early rice variety Y-liangyou 302. - Journal of Southern Agriculture.

[17] Zhou, L., Liang, S., Ponce, K., Marundon, S., Ye, G., Zhao, X. (2015): Factors affecting head rice yield and chalkiness in indica rice. - Field Crops Research 172: 1-10.

[18] Zhou, C., Huang, Y., Jia, B., Wang, Y., Wang, Y., Xu, Q., Li, R., Wang, S., Dou, F. (2018): Effects of Cultivar, Nitrogen Rate, and Planting Density on Rice-Grain Quality. Agronomy-Basel 8. 


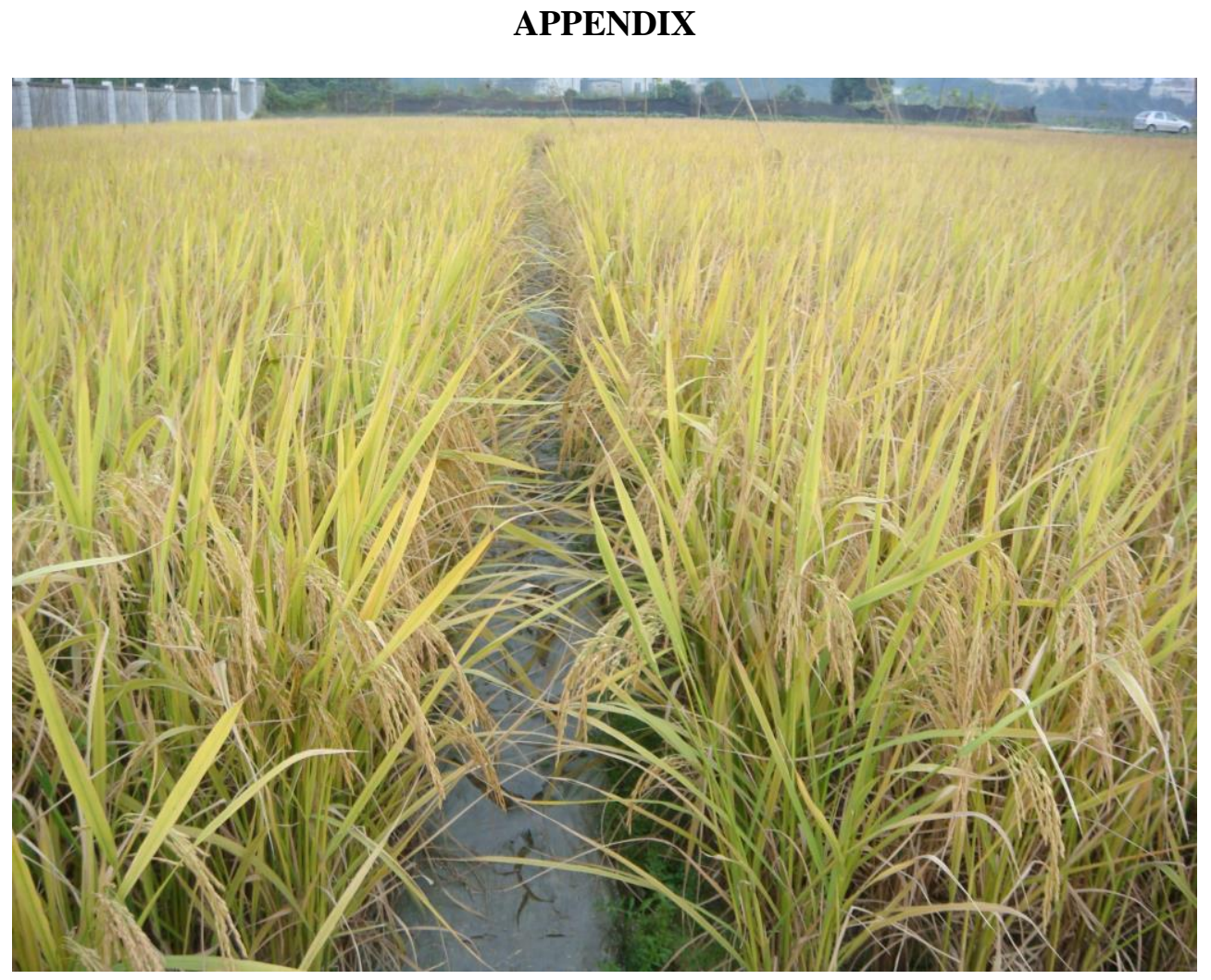

Figure A1. Photo of the experiment 